\title{
URBANIZATION DYNAMICS IN EGYPT: FACTORS, TRENDS, PERSPECTIVES
}

\author{
Julia Zinkina and Andrey Korotayev
}

\begin{abstract}
The article analyzes the specifics of urbanization dynamics in Egypt, which is noteworthy for a number of reasons. First, there was a shift from the logistic trend in the 1970s, and the share of urban population stopped growing. The UN data analysis shows that such a shift usually occurs against the background of very serious economic difficulties (and other problems associated with them). However, the urban population proportion stopped growing in Egypt when the country was experiencing a period of exceedingly rapid economic growth. We find labor migration of unprecedented scale to be the main reason which engendered this seemingly paradoxical situation. We further proceed to analyze the UN forecast on the dynamics of the Egyptian urban population proportion up to 2050, which implies a return to the logistic trend and rapid growth of the urban population share, which is fraught with socio-political instability risks. However, we present data proving that the logistic urbanization trajectory is not inevitable for Egypt, and the destabilization risks connected with the rapid increase of urban population share are largely irrelevant to Egypt in the forecasted period.
\end{abstract}

Keywords: Egypt, urbanization, migration, economic growth, forecasts, sociopolitical destabilization

\section{Logistic Trend of the Urbanization Process and the Deviations}

Urbanization is an indispensable part of the process of modernization. ${ }^{1}$ So, urbanization proves to be a significant phenomenon to regard when talking about the modernizing countries. In this respect, of great use is the UN Population Division dataset presenting evidence on the share of the urban population in various countries of the world since 1950 up to the present (the data is given in five-year periods). Moreover, basing on the known dynamics of the share of the urbanized population, the UN experts present their own forecast for the future urbanization trend in various countries up to 2050 (again presenting figures with five-year intervals).

As has been already proved in scholarly literature ${ }^{2}$ the overall urbanization macrodynamics is rather well described by a logistic model of growth. Indeed,

Julia Zinkina, Institute for African Studies, Russian Academy of Sciences and National Research University "Higher School of Economics," Moscow. Andrey Korotayev, Institute of Oriental Studies and Institute for African Studies, Russian Academy of Sciences, National Research University "Higher School of Economics" and Russian State University for the Humanities, Moscow. 
logistic growth is a kind of growth with saturation which engenders the following dynamics: an accelerating growth of an indicator (in our case, the proportion of urban population) at the beginning of the process is changed by a slowdown in the growth rates, and the process is finally concluded by a stabilization of this indicator at some particular (saturation) level (see Figure 1).

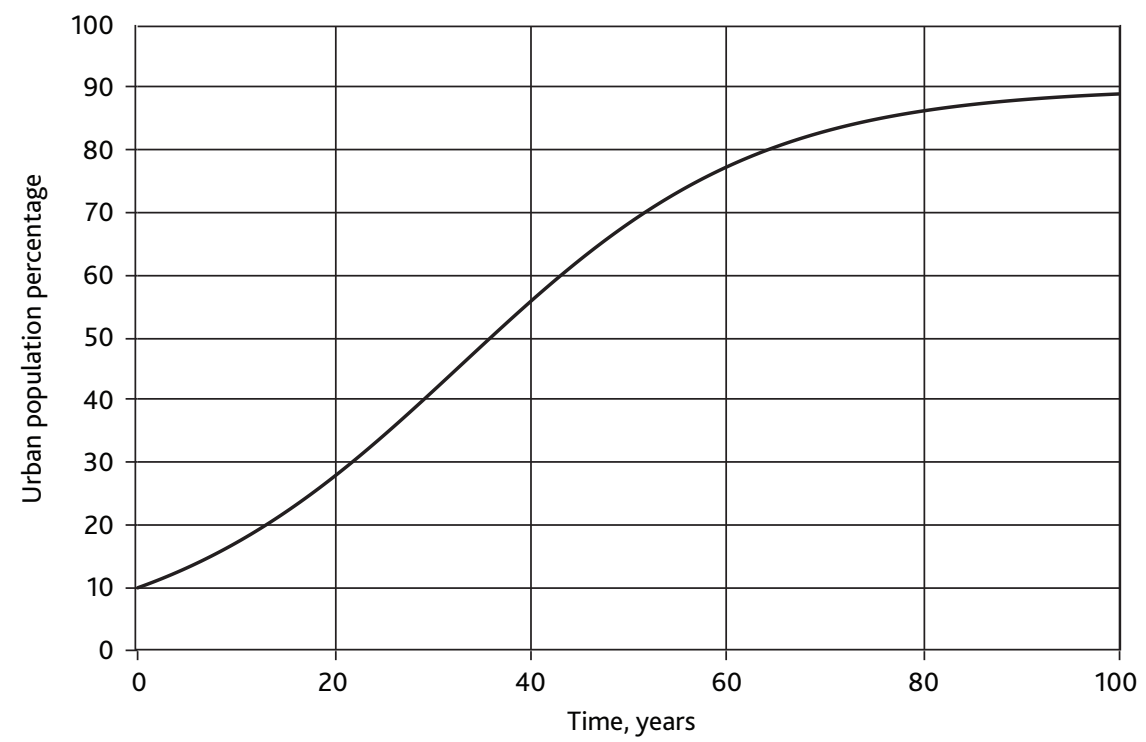

Figure 1 Example of logistic growth curve

The essence of the logistic growth of the proportion of urban population is as follows: when this proportion is rather low, the possibility of a rural dweller moving to a city is higher with the higher proportion of urban population. Indeed, the higher this proportion is, the more the probability that this rural dweller has a relative or an acquaintance residing in a city, who can supply him/her with the information necessary for committing a rural-urban migration and the initial support (as an ordinary peasant would hardly venture to move "into nowhere"). The growth of the urban population percentage tends to achieve its highest values when you have an equal number of potential and actual city-dwellers (that is with the proportion of urban population about 50 percent). However, as the proportion of the urban population exceeds 50 percent and starts approaching the saturation level, the proportion of potential city-dwellers drops more and more, and the growth rate of the variable in question slows down.

The UN Population Division data on the proportion of urban population in various countries shows that the logistic model describes rather well the unregulated 
urbanization transition in absence of strong resource limitations and is quite frequently encountered in the modernizing countries—see, for example, the Saudi case (Figure 2).

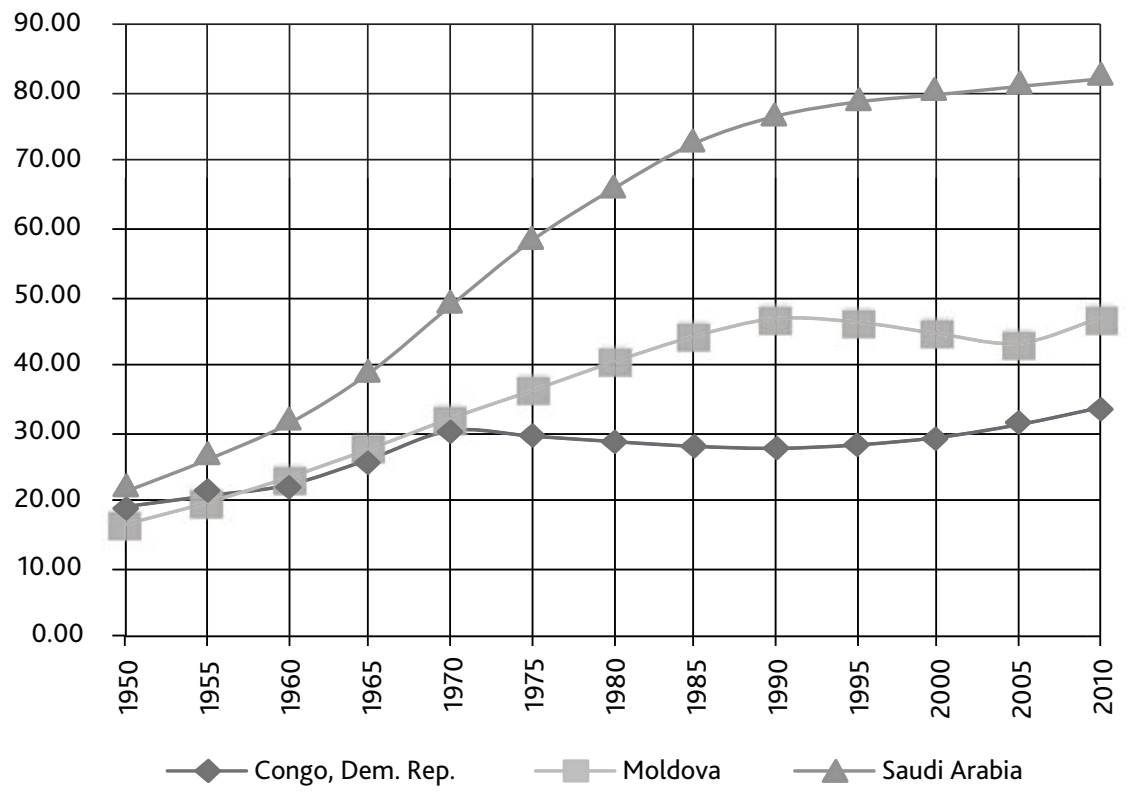

Figure 2 Dynamics of the urban population proportion, \%, Saudi Arabia, Moldova, and the Democratic Republic of Congo, 1950-2010

Source: United Nations, Department of Economic and Social Affairs, Population Division Database, http://www.un.org/ esa/population (accessed August 31, 2010).

However, in a number of countries the logistic urbanization trend was clearly interrupted at a certain point of development, being still very far from the saturation level. Our analysis shows that such a shift was commonly found against the background of economic crises, and/or major internal conflicts - generally speaking, some sociopolitical instability.

For example, in many Sub-Saharan countries deviations from the pattern of logistic growth of the proportion of the urban population occurred simultaneously with (and were actually caused by) severe economic difficulties frequently accompanied (and exacerbated) by sociopolitical instability (see, for example, Figure 2). As we see, until the 1970s the Belgian Congo/Zaire/Democratic Republic of the Congo more or less followed the logistic pattern, from which it started deviating since the 1970s as a result of severe economic problems accompanied and exacerbated by acute sociopolitical instability. ${ }^{3}$ 
Note also that the growth of the urban population proportion strongly deviated from the logistic trend since the late 1980s in most of the post-socialist countries of Europe, Transcaucasia, during the period of economic difficulties (frequently accompanied by socio-political upheavals) associated with the post-socialist transition (see, for example, Figure 2).

Egypt also experienced not only a deviation from the logistic urbanization growth pattern, but also a decline in the proportion of the urban population. Let us now turn to investigating the specifics of the urbanization process in Egypt in the second half of the twentieth century.

\section{Urbanization in Egypt}

Egypt currently possesses the largest population in the MENA region. After 1952 the Egyptian population was growing very fast, doubling in 30 years from 21,200,000 in 1950 to $42,600,000$ in 1980. In the following 30 years the population of Egypt nearly doubled once more, reaching 81,700,000 in 2008; ${ }^{4}$ so, since 1952 the Egyptian population has almost quadrupled.

As Egypt was undergoing active modernization processes in the twentieth century, it seems reasonable to expect that the urban population should have increased very significantly both in its numbers and proportion. According to the Egyptian census data, urban population increased nine-fold from 1897 to 1976, while the whole population increased fourfold. ${ }^{5}$ The largest city, Cairo, far outpaced other cities in its growth. Indeed, in 1966, 20.4 percent of Egyptians lived in Cairo; that is, half of all Egyptian urban dwellers (urban population proportion was 40.4 percent in 1966).

In the last three decades, total population and urban population were growing rather proportionately, both having nearly doubled. Thus, urban population number went up from $19,500,000$ in 1980 to $35,500,000$ in $2009 .{ }^{6}$

Though the urban population has increased remarkably in its absolute numbers, the urban population proportion demonstrates rather different dynamics. Indeed, the period of rapid urban population percentage growth was succeeded by stabilization, and then a decline in the urban population proportion (see Figure 3).

In 1960-65 the absolute number of Egyptian urban population was growing very fast (at 3.88-4.27 percent p.a.), then somewhat slower in 1966-75 (at 3.21-2.75 percent p.a.), and after that it was stable until the mid-1980s (as the urban population growth rate was nearly the same as the general population growth rate). After 1985 the proportion of the urban population declined by about 1 percent (from 43.9 percent in 1985 to 42.8 percent in 1995), being rather stable after that. The share of Cairo citizens stopped growing as well, even earlier than the general urbanization level became stable. ${ }^{7}$ 


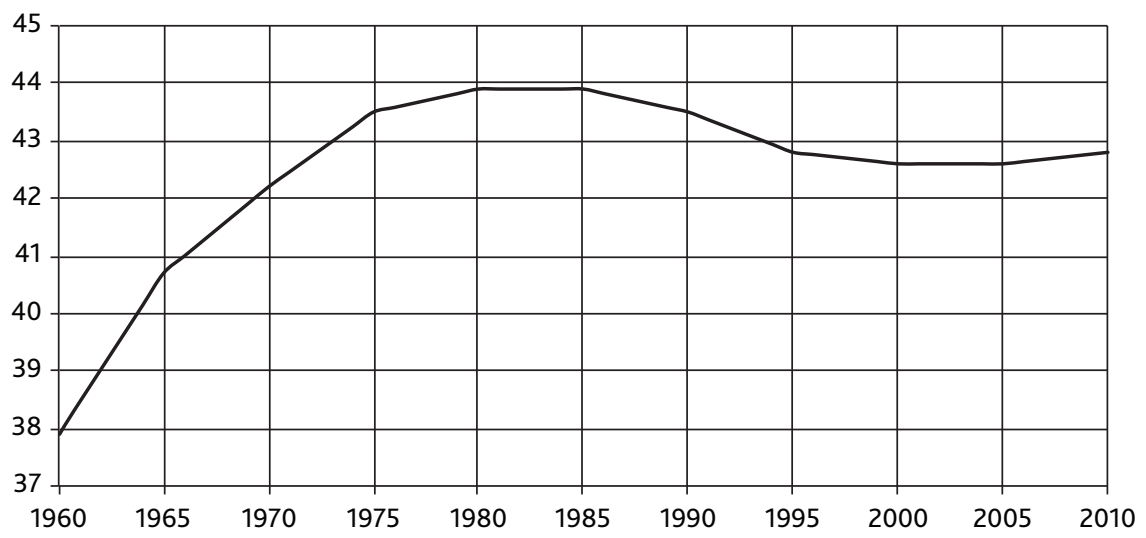

Figure 3 Urban population proportion dynamics in Egypt, \%

Source: World Bank, "World Development Indicators."

Hence, though (as in many other developing countries) in Egypt the urban population had been growing at a much higher speed than the general population until the early 1980s, in the mid-1980s the urban population growth rate became more or less equal to the general population growth rate, and then fell below it (see Figure 4): severe economic difficulties or even an economic failure, frequently accompanied (and exacerbated) by sociopolitical instability.

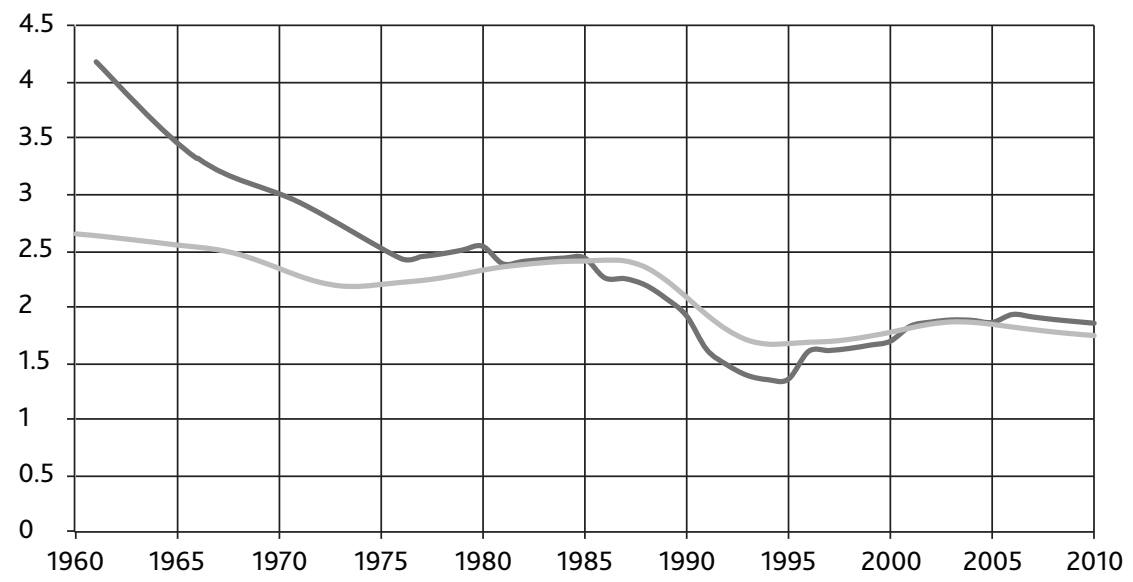

_-Annual urban population growth rate, \% _ Annual population growth rate, \%

Figure 4 Urban and total population growth rates, \%, 1960-2008

Source: World Bank, "World Development Indicators." 
Why did the urban population proportion stop growing in Egypt at a point which was far below the saturation level? (See Table 1.) As has been mentioned in the preceding section, such a discontinuation of growth of the urban population proportion is usually observed against the background of some severe economic difficulties or even an economic failure, frequently accompanied (and exacerbated) by sociopolitical instability.

Table 1 Population growth rates: rural, urban, and Egypt as a whole, \%

\begin{tabular}{lccc}
\hline Years & Urban & Rural & Total (Egypt) \\
\hline $1927-37$ & 1.7 & 1 & 1.2 \\
$1937-47$ & 3.5 & 1 & 1.8 \\
$1947-60$ & 3.4 & 2 & 2.3 \\
$1960-66$ & 3.5 & 1.6 & 2.3 \\
$1966-76$ & 2.9 & 1.5 & 2.1 \\
$1976-86$ & 2.8 & 2.8 & 2.8 \\
$1986-96$ & 1.8 & 2.3 & 2.1 \\
\hline
\end{tabular}

Source: Cairo Demographic Centre, Population of Egypt in the 20th Century (Cairo: Cairo Demographic Centre, 2003).

At first sight, the situation was much the same in Egypt, as urban population proportion ceased growing almost simultaneously with the sociopolitical crisis of 1977 when a series of demonstrations and mass protests rolled across the country. It was the largest protest action since 1952, known as the "bread riots." The riots took place in all the large Egyptian cities, several hundred thousand people participated in them, and no fewer than 800 fell victim as a result. ${ }^{8}$ One may suppose that, as the "bread riots" participants were clearly protesting against the lack of food, ${ }^{9}$ the state must have been undergoing severe economic difficulties. Besides, a number of researchers stated that the economic policy of infitah carried out by Egyptian President Anwar Sadat turned out to be unsuccessful, failed to achieve its main goals, and brought the country to a structural economic conundrum. ${ }^{10}$ In such a case it seems quite logical that the proportion of urban population should stop growing. Are we not dealing here with just one more case when the urban population percentage growth curve departed from the logistic pattern as a result of severe economic difficulties or even an economic failure accompanied (and exacerbated) by sociopolitical instability?

However, the data presented and analyzed in the next sections will demonstrate that this assumption is rather far from the reality.

\section{Daily Calorie Intake in Egypt}

Bearing in mind that the 1977 protests are usually denoted as "bread riots," let us regard the dynamics of per capita food consumption in 1961-2007 in Egypt 
according to the data collected and published by the UN Food and Agriculture Organization (FAO) (see Figure 5).

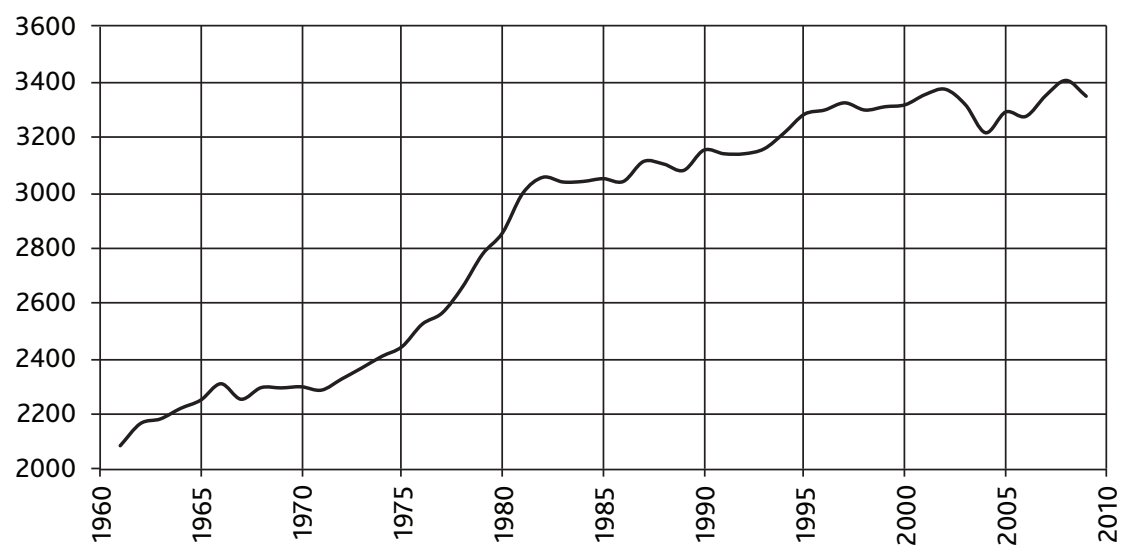

Figure 5 Per capita food consumption, 1961-2007, kcal/capita/day

Source: FAO (Food and Agriculture Organization of the United Nations), "FAOSTAT. Food and Agriculture Organization Statistics," http://faostat.fao.org/ (accessed August 21, 2010).

Unfortunately, the FAO does not present data for daily calorie intake in Egypt for the early years of Gamal Abdel Nasser's rule. Yet, FAO data indicate that in the early 1960s in Egypt the problem of malnutrition was rather serious and the average per capita food consumption was well below the norm of 2,300-2,400 kcal/day recommended by the World Health Organization (WHO). ${ }^{11}$ However, it can be seen from Figure 5 that in 1960-67 Egypt achieved remarkable success in supplying food for the population, and per capita food consumption increased by $200 \mathrm{kcal} /$ capita/day over seven years. However, further growth of this indicator was interrupted by the 1967 Arab-Israeli War, after which per capita food consumption remained at the level of 1967 until 1973.

After 1973 (during the infitah policy) per capita consumption was growing very fast. In 1982 it exceeded the level of 3,000 kcal/capita/day and never fell below this level afterwards (thus, the problem of overeating became more actual for the majority of Egyptians than undernourishment). Such a rapid growth in per capita food consumption correlated with a significant GDP per capita growth (it grew almost twofold during 1970-82). ${ }^{12}$ This fact proves the success of infitah policy. Thus, in 1977 per capita food consumption was 2,600 kcal/capita/day, which was higher than the WHO recommended norm. Moreover, daily calorie intake improved greatly, growing by $300 \mathrm{kcal} /$ capita/day in 1971-77. 
Obviously, "bread riots" in such a situation could not be a sign of undernourishment in Egypt. The reason which provoked the crisis was rather connected with food price increase and with food subsidies. The 1977 riots participants protested against subsidy cuts (which stemmed from the negotiations between the Egyptian government and the International Monetary Fund in 1976 over a package of economic reforms) combined with sharp price increases for some non-subsidized items. ${ }^{13}$

So, the situation with calorie intake was greatly improving in Egypt throughout the whole decade of the 1970s. How could such remarkable achievements possibly have been made in the period of the allegedly "unsuccessful" economic policy of infitah? Let us then further look into Egyptian economic development at that time in order to understand what was happening to the Egyptian economy and whether the discontinuation of urban population proportion growth should be attributed to economic reasons.

\section{Economic Development}

Figures 6 and 7 reveal the dynamics of such key indicators of Egyptian economic development as GDP and GDP per capita from 1950 until 2008 in 1990 constant international dollars. The dynamics of economic growth indicators revealed in the two graphs allows specifying several periods within the Egyptian economic history in the second half of the twentieth century as well as the early twenty-first century.

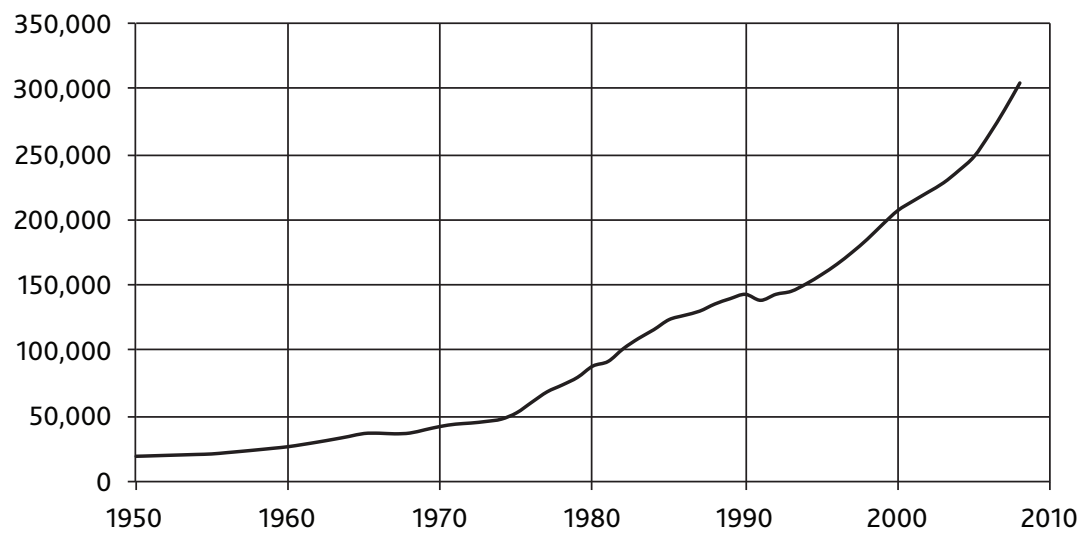

Figure 6 GDP, millions of 1990 constant international dollars, 1950-2008

Source: Angus Maddison, "World Population, GDP and Per Capita GDP, A.D. 1-2003," http://www.ggdc.net/maddison (accessed July 16, 2010). 


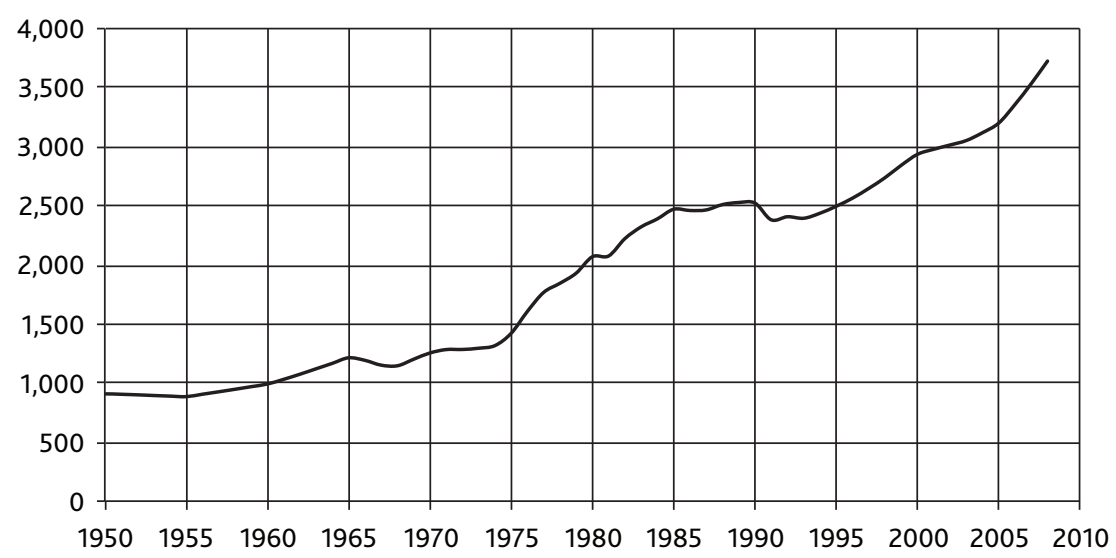

Figure 7 GDP per capita, 1990 constant international dollars, 1950-2008

Source: Angus Maddison, “World Population, GDP and Per Capita GDP, A.D. 1-2003," http://www.ggdc.net/maddison (accessed July 16, 2010).

The period of 1962-73 in Egypt can be named the time of rather strict economy planning. The main instruments of state economy regulation were investment planning and price regulation. The role of the private sector was limited. The government was also carrying out the policy of import substitution. Considerable attention was given to developing infrastructure and the social sector. ${ }^{14}$

At that time GDP was growing rather fast, increasing from $\$ 30.26$ billion to $\$ 45.92$ billion (here and below 1990 constant international dollars are used as a unit of measurement for GDP) over eleven years. It should be noted that the rapid GDP increase at that time was accompanied by an exceedingly fast population growth which "ate up" a significant portion of the economic successes; so, GDP per capita was increasing quite slowly, from $\$ 1,074$ in 1962 to $\$ 1,294$ in 1973 (and was even decreasing in 1964-67).

Figure 8 reveals that in the time of centralized economy (1960-73) GDP growth rates and GDP per capita growth rates were rather high, but their positive dynamics were twice interrupted by wars. Indeed, in 1967 and in 1973 the GDP growth rate was less than 1 percent, and GDP per capita growth acquired negative values.

After the 1973 Arab-Israeli War the Egyptian internal economic policy was liable to significant structural changes. Anwar as-Sadat, the President of Egypt, declared the course towards economy reformation and liberalization, which got the name of infitah. The main aim of this policy was to increase economic growth rates and productive efficiency. The achievement of these goals was supported by a set of reforms, such as trade liberalization, gradual economy decentralization, and active export stimulation. A considerable role was given to the private sector. ${ }^{15}$ 


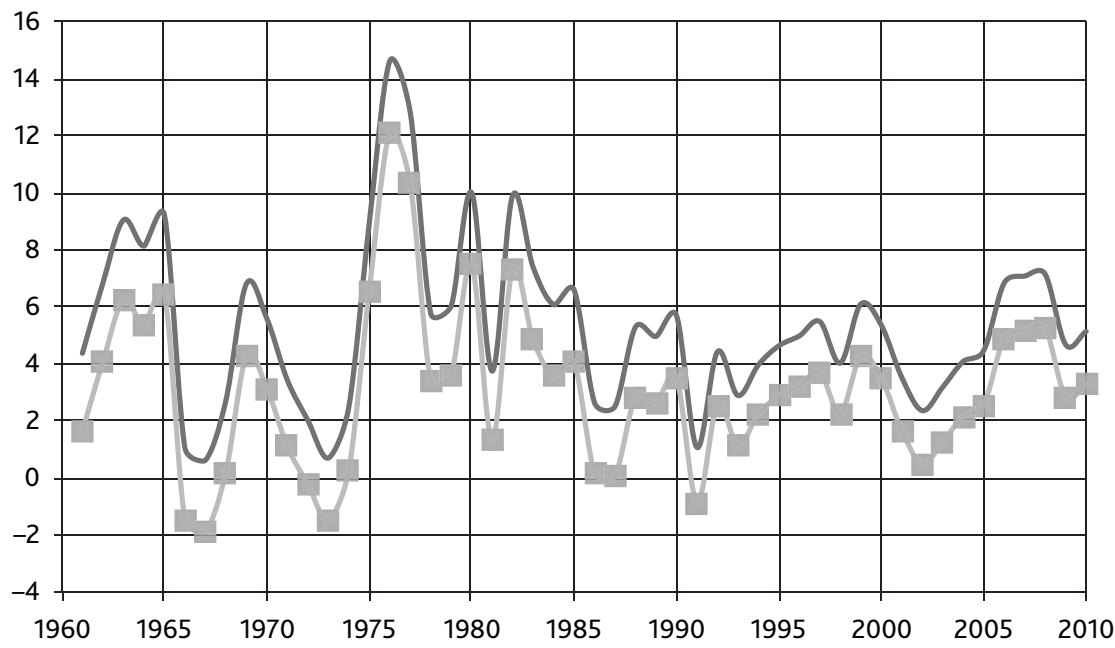

GDP growth rate, annual, \%

GDP per capita growth rate, annual, \%

Figure 8 GDP growth rate and GDP per capita growth rate, $\%$

Source: World Bank, "World Development Indicators."

Figure 8 shows that after Anwar as-Sadat introduced the measures of economy liberalization, the rates of GDP and GDP per capita growth literally rocketed up, reaching their peaks in 1976 (14.63 percent and 12.14 percent respectively). Moreover, in 1973-85 both indicators grew much more significantly than in the previous period (Figures 6 and 7). Thus, GDP grew from \$45.92 billion in 1973 to $\$ 123.674$ billion in 1985 - that is, by 2.7 times over twelve years. At the same time, GDP per capita grew from $\$ 1,294$ to $\$ 2,471$ —about twofold.

Indeed, the Egyptian population grew impetuously in Sadat's epoch, increasing by more than a third (36.1 percent) over twelve years (1970-82). However, Egyptian economic growth was even more impetuous during that period, with Egyptian GDP growing by 141.1 percent in 1970-82, the major part of this growth taking place in the course of infitah policy. As a result, GDP per capita nearly doubled during the same period, which predictably correlated with an exceedingly fast growth of per capita calorie intake (see Figure 9 and Table 2). ${ }^{16}$

Obviously, during infitah the key economic indicators grew much faster than in the period of centralized economy. Thus, the main goal of infitah, namely stimulation of economic growth, was achieved. As regards investment, infitah policy proved to be quite successful in this sphere as well: "Domestic public investment between 1973 and 1980 gained by roughly $26 \%$, and private investment by $78 \%$. New foreign private (non-oil) investment, though still below expectations, climbed to above $\$ 400$ 


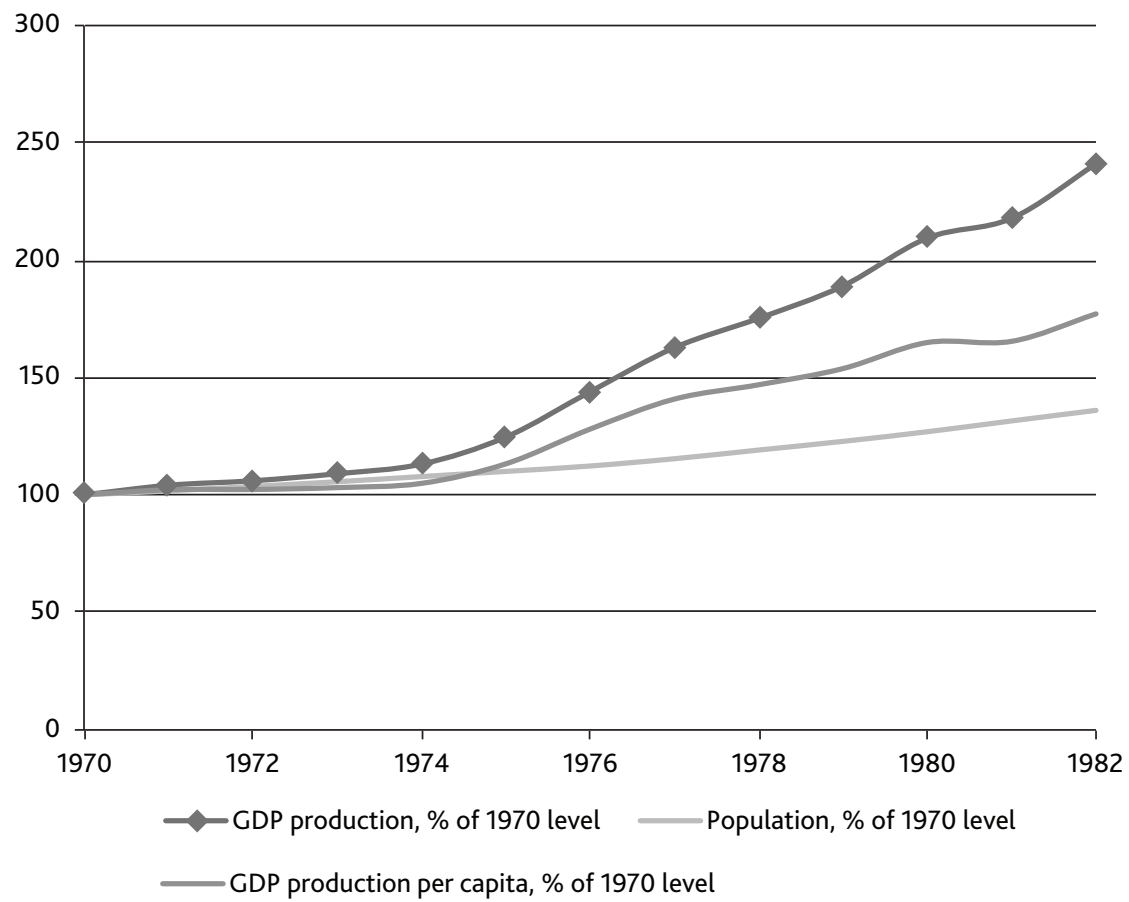

Figure 9 Economic and demographic dynamics of Egypt, 1970-82 (1970=100)

Sources: Angus Maddison, Monitoring the World Economy: A Millennial Perspective (Paris: OECD, 2001); Angus Maddison, "World Population, GDP and Per Capita GDP, A.D. 1-2003," http://www.ggdc.net/maddison (accessed July 16, 2010); FAO (Food and Agriculture Organization of the United Nations), "FAOSTAT. Food and Agriculture Organization Statistics," http://faostat.fao.org/ (accessed August 21, 2010).

million yearly by 1980 , up from just $\$ 100$ million three years ago.”17 In 1974-77 the share of foreign investment in Egypt was 67 percent (compared to 29 percent in the decade preceding the infitah policy), including grants and loans from Gulf countries, as well as medium- and long-term aid from Western countries, and various projects of international organizations..$^{18}$ The percentage of people living on one US dollar or less per capita per day decreased from 65 percent in 1974-75 (launch of infitah), to only 18 percent in $1982^{19}$ - a 3.5 -fold decrease in less than a decade!

What were the reasons for such a success? First of all, national income from oil exports greatly increased thanks to oil prices rocketing in 1973, after which Egypt increased the volume of its oil exports from 2 million barrels in 1974 to 149 million barrels in 1982. Accordingly, the national income from oil exports increased from $\$ 53$ million in 1971-72 to $\$ 2.76$ billion in 1981-82. ${ }^{20}$

In June 1975 exploitation of the Suez Canal resumed, and that contributed a substantial part of Egyptian national income. Indeed, the total share of oil exports 
Table 2 Economic and demographic dynamics of Egypt in the Sadat epoch (1970-82)

\begin{tabular}{|c|c|c|c|c|c|c|c|}
\hline \multirow[t]{2}{*}{ Year } & \multicolumn{2}{|c|}{$\begin{array}{l}\text { Economic growth 1: } \\
\text { aggregate GDP production }\end{array}$} & \multicolumn{2}{|c|}{$\begin{array}{l}\text { Demographic } \\
\text { growth: population }\end{array}$} & \multicolumn{2}{|c|}{$\begin{array}{c}\text { Economic growth 2: GDP } \\
\text { production per capita }\end{array}$} & \multirow{2}{*}{$\begin{array}{c}\text { Per capita food } \\
\text { consumption } \\
\text { Kcal/capita/day }\end{array}$} \\
\hline & $\begin{array}{c}\text { Billions of } 1990 \\
\text { international } \\
\text { dollars (PPP) }\end{array}$ & $\begin{array}{c}\% \text { of } 1970 \\
\text { level }\end{array}$ & Millions & $\begin{array}{c}\% \text { of } 1970 \\
\text { level }\end{array}$ & $\begin{array}{c}\text { In } 1990 \text { constant } \\
\text { international } \\
\text { dollars }\end{array}$ & $\begin{array}{l}\% \text { of } \\
1970 \\
\text { level }\end{array}$ & \\
\hline 1970 & 42.1 & 100.0 & 33.6 & 100.0 & 1,254 & 100.0 & 2,355 \\
\hline 1971 & 43.9 & 104.2 & 34.2 & 101.8 & 1,283 & 102.3 & 2,341 \\
\hline 1972 & 44.7 & 106.1 & 34.8 & 103.7 & 1,284 & 102.4 & 2,361 \\
\hline 1973 & 45.9 & 109.1 & 35.5 & 105.7 & 1,294 & 103.2 & 2,376 \\
\hline 1974 & 47.7 & 113.2 & 36.2 & 107.9 & 1,317 & 105.0 & 2,443 \\
\hline 1975 & 52.5 & 124.7 & 37.0 & 110.1 & 1,421 & 113.3 & 2,481 \\
\hline 1976 & 60.6 & 144.0 & 37.7 & 112.4 & 1,606 & 128.1 & 2,555 \\
\hline 1977 & 68.5 & 162.8 & 38.8 & 115.5 & 1,767 & 140.9 & 2,600 \\
\hline 1978 & 73.8 & 175.3 & 40.0 & 119.2 & 1,844 & 147.0 & 2,702 \\
\hline 1979 & 79.6 & 189.1 & 41.3 & 122.9 & 1,930 & 153.9 & 2,811 \\
\hline 1980 & 88.2 & 209.5 & 42.6 & 127.0 & 2,069 & 165.0 & 2,887 \\
\hline 1981 & 91.7 & 217.9 & 44.2 & 131.6 & 2,076 & 165.5 & 2,992 \\
\hline 1982 & 101.5 & 241.1 & 45.7 & 136.1 & 2,223 & 177.2 & 3,067 \\
\hline
\end{tabular}

Sources: Angus Maddison, Monitoring the World Economy: A Millennial Perspective (Paris: OECD, 2001); Angus Maddison, "World Population, GDP and Per Capita GDP, A.D. 1-2003," http://www.ggdc.net/maddison (accessed July 16, 2010); FAO (Food and Agriculture Organization of the United Nations), "FAOSTAT. Food and Agriculture Organization Statistics," http://faostat.fao.org/ (accessed August 21, 2010).

and Suez Canal within the national income increased from 5 percent in 1975 to about 35 percent in $1985 .{ }^{21}$ A newly emerged significant source of income was the remittances obtained from Egyptian labor migrants (this phenomenon will be viewed in greater detail in the next section).

Another actively developing sphere was tourism, which benefited from the increased prosperity of Gulf citizens (due to oil price hikes). Indeed, the number of tourists coming to Egypt from the Gulf increased by an order of magnitude: besides, investors from Arab oil-producing countries considered Egyptian tourism to be a promising sphere of investment and contributed funds to the building of hotels. $^{22}$

On the whole, the following factors of Egyptian rapid economic growth during the infitah policy can be named: increase of oil export income due to global oil price rises (which induced Egypt to increase the volume of its oil exports by an order of magnitude); the resumption of Suez Canal exploitation in June 1975; state policy of labor migration encouragement (see next section for details) which brought about the increase of remittances received from Egyptian labor migrants (especially from the Gulf oil-producing countries); tourism development; economic liberalization, direct foreign investments, and foreign aid. ${ }^{23}$ 
Overall, quite contrary to what could be expected, the urban population proportion stopped growing when Egypt was going through a period of truly remarkable economic successes.

Moreover, there is one more aspect to be mentioned. The second half of the twentieth century was a time of agriculture modernization in Egypt. This led to labor productivity growth in agriculture, and fewer workers were required to do agricultural work; accordingly, the excess workforce (mostly youths) should have been moving to cities in search of work. ${ }^{24}$ Let us consider at this point the dynamics of labor productivity growth in Egyptian agriculture (see Figure 10).

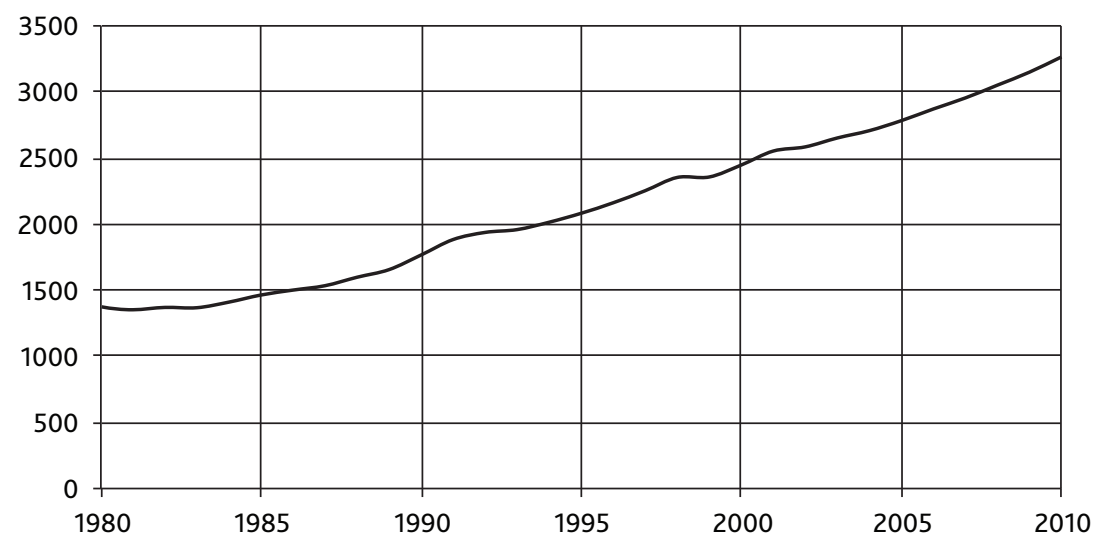

Figure 10 Labor productivity growth in Egyptian agriculture (constant 2000 international dollars per worker), $1980-2010$

Source: World Bank, "World Development Indicators."

The fastest growth of agricultural labor productivity was observed in Egypt from 1977 to the early 1990s. It would be reasonable to expect that in this period the excessive rural workforce should actively migrate to cities, causing the urbanization level to grow intensely. However, the reality was contrary to these assumptions - as we have mentioned already, after 1975 the urbanization rates slowed down, stabilized after 1980, and had negative values from the mid-1980s until the mid-1990s. Obviously, some other factors were strongly influencing the urbanization dynamics in Egypt.

\section{Labor Migration and Its Influence Upon Urbanization}

In our opinion, the explanation for the peculiarities of the urban population proportion dynamics should largely be attributed to the phenomenon of migration. 
The phenomenon of massive Egyptian labor migration was a significant mark of Sadat's epoch. Before 1966 the state put limitations upon the migration of technical specialists and qualified workforce. After some limitations were lifted up, qualified specialists began emigrating from Egypt to developed countries in rather large numbers. ${ }^{25}$ The government officially permitted constant and temporary emigration in 1971, while in 1974 the limitations regarding labor migration were cancelled.

It is well known that oil price hikes in 1973-74 had a considerable impact upon labor force migration in the Arab region. ${ }^{26}$ Namely, in the mid-1970s massive labor migration did start from Egypt to Arab oil-producing countries (working-age males comprised the majority of migrants). According to official Egyptian data, 1,400,000 Egyptians resided abroad in 1976, 600,000 of whom were economically active. ${ }^{27}$ The number of migrants was increasing so fast that in 1981 the government decided to establish a special Ministry of Manpower and Emigration. In 1985 the number of such migrants, according to different data, was about 2.5-3.5 million-that is, almost 10-13 percent of the Egyptian labor force. ${ }^{28}$

After oil prices fell in the mid-1980s the demand for Egyptian workers in the Gulf countries stopped increasing. This observation is supported by the fact that in 1988 natural and real population growth rates became even when after the oil price fall of the mid-1980s (with a quite obvious small lag) the number of Egyptians getting permission to work abroad decreased significantly; indeed, taking 1988 as a base year, the number of Egyptian contracts halved in 1989. ${ }^{29}$

As regards the 1991 Gulf War, some Egyptians (particularly those working in Kuwait and Iraq) returned home. However, the majority of permissions for working abroad were prolonged, and no massive return of migrants occurred (which would have created a serious burden on the Egyptian economy). ${ }^{30}$ However, afterwards the real population growth rate once more became lower than the natural increase (though not to the same extent as in late 1970s). This means that migration resumed, but did not reach the same scale as during the oil boom.

In our opinion, wide-scale labor migration was the crucial factor behind the discontinuation of the urban population proportion growth. We assume that after the mid-1970s the newly-emerged work opportunities in the oil-producing Arab countries had a determining impact upon the urbanization dynamics in Egypt. ${ }^{31}$

Indeed, a major part of rural-urban migration was labor migration (i.e. rural dwellers searching for work in cities). After the "oil boom" the oil-producing Arab countries offered a great number of workplaces (even low-qualified) which were lucrative from the Egyptian point of view. So, a great part of rural labor migrants preferred to go to these countries, rather than to Egyptian cities; moreover, the share of rural dwellers among Egyptian labor migrants was increasing with time. ${ }^{32}$

As a result, the growth of Egyptian cities became visibly slower. While rapid urban population growth is accounted for by a combination of natural population 
increase and intense rural-urban migrations, after the mid-1970s the contribution of a migration factor decreased considerably. Thus, in 1960-75 migrations accounted for 22 percent of Cairo population growth, but in 1975-85 this share was only 10 percent and migrants mostly came to Cairo not from villages, but from small towns. ${ }^{33}$ For example, in 1976 there were 2.6 million urban-urban migrants, but fewer than 1 million rural-urban migrants; in 1986 these figures changed to 3 million and 540,000 respectively; besides, 423,000 Egyptians migrated from urban areas to rural areas. In 1996 there were 2.5 million urban-urban migrants, 950,000 urban-rural migrants, and only 562,000 rural-urban migrants, ${ }^{34}$ so the share of urban population was bound to be stable or decrease (an increase was then out of the question). Besides, urban residents also represented a considerable proportion of labor migrants to oil-producing Arab countries (especially among the highly qualified workforce). So, under the impact of all these factors, the share of urban population was declining.

\section{Agricultural Employment Reduction}

A relatively low proportion of urban population and a discontinuation of its growth far below the saturation level are frequently connected with high agricultural employment (and low agricultural productivity); this pattern can be observed, for example, in many Sub-Saharan countries. However, Egypt looks quite well in this regard; the share of population employed in agriculture was 42.4 percent in 1980 and 39 percent in 1990, then its decline got faster, and in 2000 only 29.6 percent of Egyptians worked in agriculture. In the meantime, as we can see above, the proportion of rural population employed in non-agricultural activities increased from 24.85 percent in 1989 to 52.09 percent in 2002 . At the moment only about half of the Egyptian rural population is engaged in agriculture (see Figure 11).

In terms of rural population employed in non-agricultural activities, the most natural explanation is the development of industrial and service sectors in rural areas, as well as some village dwellers working in cities. However, when talking about the Egyptian case, another factor should also be taken into account: the issue of statistical nominations.

Though according to government statistics Egypt remains a largely rural country, many villages have expanded, some to over 100,000 inhabitants, but have not been reclassified as towns. ${ }^{35}$ Indeed, official Egyptian sources claim the number of Egyptian villages to be somewhere between 4,300 and 4,500. ${ }^{36}$ Assuming that the Egyptian population could not have been less than 80 million in 2010 (or even 84.5 million according to the $\mathrm{UN}$ ), and no more than 43 percent reside in urban areas, we conclude that from 45.6 to 48 million Egyptians dwell in these 4,300-4,500 villages. This puts the population of a medium-sized Egyptian village at 10,000 to 10,500 people; naturally, as there are villages with much lower populations, there invariably 


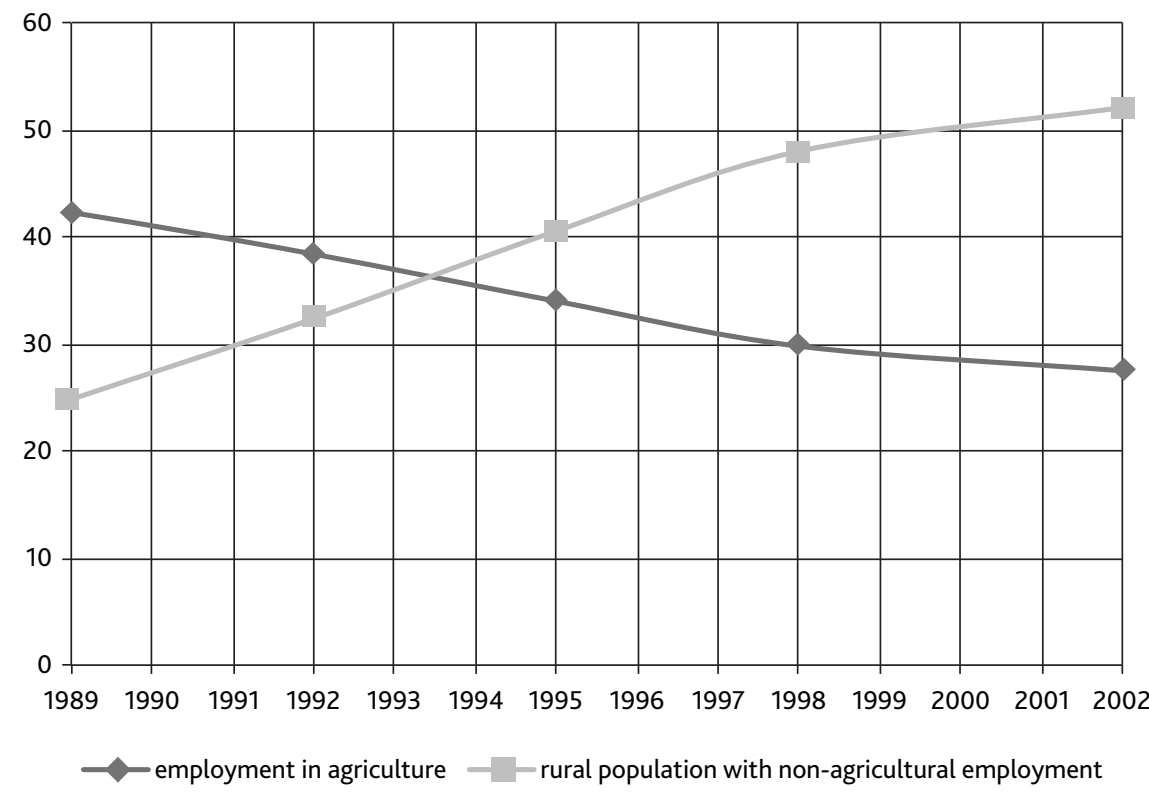

Figure 11 Share of workforce employed in agriculture and share of rural population engaged in nonagricultural activities in Egypt

Source: World Bank, "World Development Indicators."

exist villages with much greater populations. According to global standards, these "villages" with more than 10,000 dwellers ought to be classified as small towns (which would account for a prevalence of non-agricultural employment), but, as has been mentioned above, in this respect Egyptian statistics failed to keep pace with the rate of village population growth, and reclassification of the kind is yet to be expected.

With respect to what has been said in the previous section, it seems reasonable to regard the UN urbanization forecast for Egypt (Figure 12). UN experts forecast a rapid growth of Egyptian urbanization level, from 42.8 percent in 2010 to 62.4 percent in 2050 (up by 1.5 times over 40 years), while the absolute number of urban residents is forecast to more than double, from 34 to 75.6 million. Note that such a rapid growth would imply high risks of sociopolitical destabilization. ${ }^{37}$

However, in light of what has been said above (especially regarding the town-sized Egyptian villages), we can maintain with a high degree of probability that the UN forecast does not imply a sharp acceleration in rural-urban migration (it seems rather unlikely in the light of the previous dynamics of Egyptian internal migration), but will be provided for by large "villages" (with over 10,000 inhabitants) gradually acquiring the status of towns. 


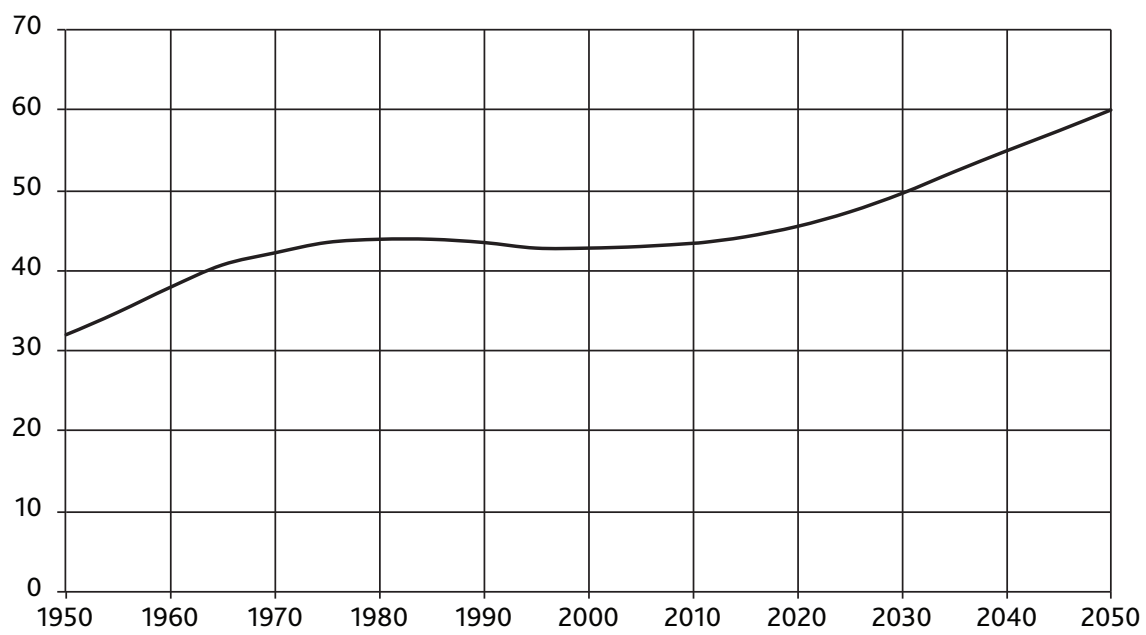

Figure 12 Urban population proportion in Egypt, \%, with forecast up to 2050

Source: United Nations, Department of Economic and Social Affairs, Population Division Database, http://www.un.org/ esa/population (accessed August 31, 2010).

\section{Notes}

1. See, for example, Gino Germani, ed., Modernization, Urbanization, and the Urban Crisis (Boston: Little, Brown and Company, 1973). See also Luisito Bertinelli and Duncan Black, "Urbanization and Growth," Journal of Urban Economics 56 (2004), 80-96. James C. Davis and J. Vernon Henderson, "Evidence on the Political Economy of the Urbanization Process," Journal of Urban Economics 53 (2003), 98-125. York W. Bradshaw, "Urbanization and Underdevelopment: A Global Study of Modernization, Urban Bias, and Economic Dependency," American Sociological Review 52:2 (1987), 224-239. Bruce London and David A. Smith, "Urban Bias, Dependence, and Economic Stagnation in Noncore Nations," American Sociological Review 53:3 (1988), 224-239.

2. See, for example, Michael Pacione, Urban Geography: A Global Perspective (3rd ed.) (Routledge, 2009).

3. See, for example, K. N. Emizet, "Political Cleavages in a Democratizing Society: The Case of the Congo (Formerly Zaire)," Comparative Political Studies 32 (1999).

4. Angus Maddison, "World Population, GDP and Per Capita GDP, A.D. 1-2003," http://www.ggdc. net/maddison (accessed July 16, 2010).

5. M. S. Abdel Hakim and W. Abdel Hamid, "Some Aspects of Urbanisation in Egypt," Centre for Middle Eastern and Islamic Studies Working Paper (University of Durham, 1982).

6. United Nations, "Population Division Database."

7. F. Shorter, "Cairo's Leap Forward: People, Households, and Dwelling Spaces," Cairo Papers in Social Science 12:1 (Cairo: The AUC Press, 1989), 5.

8. D. Hirst, "How High Life and Scandal Rocked Sadat," MERIP Reports 54 (1977), 19-20.

9. Indeed, did not one of the slogans chanted by the Bread Riot participants sound as follows: Yā bațal al- 'ubūr! Fèn al-futūr? "Hero of the Crossing, where is [our] breakfast?" (addressing President Sadat).

10. J. Tucker, "While Sadat Shuffles: Economic Decay, Political Ferment in Egypt," MERIP Reports 65 (1978), 3-9+26. 
11. L. Naiken, "FAO Methodology for Estimating the Prevalence of Undernourishment," Paper presented at International Scientific Symposium on Measurement and Assessment of Food Deprivation and Undernutrition, Rome, 2002.

12. Andrey Korotayev, Daria Khaltourina, Artemy Malkov, Justislav Bogevolnov, Svetlana Kobzeva, and Julia Zinkina, Mathematical Modeling and Forecasting World and Regional Development (Moscow: KomKniga, 2010), in Russian, p. 168. Andrey Korotayev, Julia Zinkina, Svetlana Kobzeva, Justislav Bogevolnov, Daria Khaltourina, Artemy Malkov, and Sergey Malkov, “A Trap at the Escape from the Trap? Demographic-Structural Factors of Political Instability in Modern Africa and West Asia," Cliodynamics: The Journal of Theoretical and Mathematical History 2:2 (2011), 276-303 (Appendix D).

13. A. U. Ahmed, H. E. Bouis, T. Gutner, and H. Lofgren, The Egyptian Food Subsidy System: Structure, Performance, and Options for Reform (Washington, DC: International Food Policy Research Institute, 2001), 7.

14. Anton Dobronogov and Farrukh Iqbal, "Economic Growth in Egypt: Constraints and Determinants," The World Bank Middle East and North Africa Working Paper Series 42/34510 (2005), 2. Heba Handoussa, Mieko Nishimizu, and John Page, "Productivity Change in Egyptian Public Sector Industries after the 'Opening', 1973-1979," Journal of Development Economics 20 (1986), 53-73, at 54 .

15. Handoussa, Nishimizu, and Page, "Productivity Change," 54.

16. Korotayev et al., "Mathematical Modeling," 167-168; Korotayev et al., "A Trap at the Escape from the Trap," Appendix D.

17. Marvin Weinbaum, "Egypt's 'Infitah' and the Politics of US Economic Assistance," Middle Eastern Studies 21:2 (1985), 206-222, at 215, 216.

18. Victor Levy, "The Savings Gap and the Productivity of Foreign Aid to a Developing Economy: Egypt," The Journal of Developing Areas 19:1 (1984), 21-34.

19. B. Hansen, Egypt and Turkey (Oxford and New York: Oxford University Press, 1991), 32.

20. Nazli Choucri and M. Zaki Shafei, "Energy Policy in Egypt," Extrait de l'Egypte Contemporaine 895 (1984), 16, 7.

21. H. Handoussa, "Balance Sheet of Reform in Two Decades," in N. El-Mikawy and H. Handoussa, eds., Institutional Reform and Economic Development in Egypt (The American University of Cairo Press, 2002), 89-105.

22. Rodney Wilson, "Whither the Egyptian Economy?" British Journal of Middle Eastern Studies 20:2 (1993), 204-213, at 209.

23. Handoussa, Nishimizu, and Page, "Productivity Change," 55 ; Dobronogov and Iqbal, "Economic Growth in Egypt," 2.

24. Korotayev et al., "Mathematical Modeling," 168; Korotayev et al., "A Trap at the Escape from the Trap."

25. IOM, Contemporary Egyptian Migration 2003 (Cairo: International Organization for Migration, 2003), 20.

26. See, for example, Ismail Serageldin, James Socknat, J. Stace Birks, and Clive Sinclair, "Some Issues Related to Labor Migration in the Middle East and North Africa," Middle East Journal 38:4 (1984), 615-642, at 615.

27. J. S. Birks and C. A. Sinclair, "Egypt: A Frustrated Labor Exporter?" Middle East Journal 33:3 (1979), 288-303, at 296. Ali Dessouki, "The Shift in Egypt's Migration Policy: 1952-1978," Middle Eastern Studies 18:1 (1982), 53-68, at 54.

28. Hansen, Egypt and Turkey, 135.

29. Ayman Zohry, Interrelationships between Internal and International Migration in Egypt: A Pilot Study (American University of Cairo, 2005), 28.

30. Ralph Sell, "Egyptian International Labor Migration and Social Processes: Toward Regional Integration," International Migration Review 22:3 (1988), 87-108.

31. Shorter, "Cairo's Leap Forward," 5. 
32. Roushdy, Assaad, and Rashed, International Migration, Remittances and Household Poverty Status in Egypt (Washington, DC: The World Bank, 2009).

33. F. N. Ibrahim and B. Ibrahim, Egypt: An Economic Geography (London and New York: I. B. Tauris, 2003), 210; Shorter, "Cairo's Leap Forward," 6.

34. Zohry, Interrelationships, 15.

35. "A Special Report on Egypt. No Paradise," The Economist, July 15, 2010, http://www.economist. com/node/16564152?story_id=16564152\&fsrc=rss

36. Egypt State Information Service, "Local and Rural Development," SIS Yearbook 2006, http:// www.sis.gov.eg/en/Story.aspx?sid=2356. Yunan Labib Rizk, "Village Choice," Al-Ahram Weekly 758 (September 1-7, 2005), http://weekly.ahram.org.eg/2005/758/chrncls.htm. Nasr Sh., "SMEs Gaining Ground," Al-Ahram Weekly 1001 (June 3-9, 2010), http://weekly.ahram.org.eg/2010/1001/ ec2.htm

37. Korotayev et al., "Mathematical Modeling"; Korotayev et al., "A Trap at the Escape from the Trap." 